\title{
Plasma Magnesium, Calcium and Inorganic Phosphorus in Norwegian Semi-Domestic Female Reindeer (Rangifer tarandus tarandus) on Winter Pastures
}

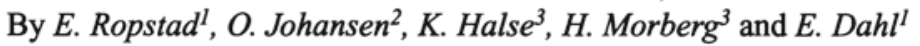 \\ ${ }^{1}$ Department of Reproduction and Forensic Medicine, and ${ }^{3}$ Department of Biochemistry, Physiology and Ani- \\ mal Nutrition, Norwegian College of Veterinary Medicine, Oslo, and ${ }^{2}$ The Directorate of Reindeer Husbandry, \\ Alta, Norway.
}

Ropstad E., O. Johansen, K. Halse, H. Morberg and E. Dahl: Plasma magnesium, calcium and inorganic phosphorus in Norwegian semi-domestic female reindeer (Rangifer tarandus tarandus) on winter pastures. Acta vet. scand. 1997, 38, 299-313. - Altogether 1645 blood plasma samples were collected from 2 reindeer (Rangifer tarandus tarandus $L$ ) herds in northern Norway (Magerøy and Sørøy), and from 2 herds in southern Norway (Filefjell and Lom) during the period from 1992 through 1995. Except for 2 subsets of samples from Lom $(\mathrm{N}=51$ and 56) all samples were collected on winter pasture between January and early March. The herds were of varying nutritional status, the Lom herd being regarded to be among the best in the country in this regard.

Plasma levels of magnesium, calcium and inorganic phosphorus were measured. In addition, plasma progesterone was used as a pregnancy test, a discriminatory level of 7 nmol $1^{-1}$ being chosen as indicating pregnancy. For the investigated minerals, the analysis of variance included effects for year of sampling, herd, pregnancy status, age and mineral status.

Average mineral concentrations varied considerably between herds and year of sampling. The overall average (SD; min-max) concentrations of plasma $\mathrm{Ca}, \mathrm{Mg}$ and $\mathrm{P}$ in samples collected on winter pastures were $2.42(0.25 ; 0.9-3.6), 0.83(0.17 ; 0.16-1.39)$ and $1.70(0,47 ; 0.2-3.4) \mathrm{mmol} \mathrm{l}^{-1}$, respectively. The overall pregnancy rate was $79.8 \%$. The frequency of subnormal plasma values within herds and years for magnesium $(\leq 0.7$ mmol $\left.\mathrm{l}^{-1}\right)$ and calcium $\left(\leq 2.2 \mathrm{mmol}^{-1}\right)$ varied between $0-61.9 \%$ and $1.4-44.9 \%$ respectively. Significant positive correlations between calcium and magnesium were found in all herds except in the Lom herd where all animals had plasma $\mathrm{Mg}$ values above $0.8 \mathrm{mmol} \mathrm{l}^{-1}$. Generally, the highest correlation coefficients were found in subsets of data with a high frequency of subnormal magnesium concentrations. Plasma magnesium showed the greatest contribution to plasma calcium variance when tested together with herd, year of sampling, pregnancy status, age and plasma inorganic phosphorus. A decrease in plasma magnesium from 1 to $<0.5 \mathrm{mmol} \mathrm{l}^{-1}$ was associated with a decrease in plasma calcium of approximately $15 \%$.

Mean plasma magnesium and calcium levels were significantly $(p<0.01)$ higher in pregnant animals than in barren females, a significant positive relationship being found between pregnancy rate and average concentrations of the same minerals when sets of observations from different herds and different years were compared.

The positive correlation between plasma calcium and magnesium in herds with subnormal magnesium minima is consistent with evidence from other species reported in the literature of impaired calcium homeostasis in magnesium deficient animals.

Minerals; nutrition; pasture; reproduction. 


\section{Introduction}

Normally, semi-domestic reindeer in Norway are subjected to extreme seasonal variations in climate and nutrition. Since no supplementary feeding is usually provided, the availability of winter grazing may be a limiting factor. In recent years, overgrazing in winter due to increasing animal populations has become a major problem, especially in Northern Norway. As a result, the nutritional status of many herds has declined, and some reports indicate that severe nutritional imbalances may occur. In this connection it should also be borne in mind that the winter diet of reindeer is dominated by lichens which are low in protein and minerals but abundant in complex carbohydrates (Nieminen \& Heiskari 1988).

Animals in the Kautokeino area in Finnmark (Hoff et al. 1993) with clinical symptoms of mineral disturbances, such as ataxia and paresis, had extremely low serum magnesium levels (mean $=0.19 \mathrm{mmol} \mathrm{l}^{-1}$ ) and moderately reduced levels of serum calcium $\left(2.03 \mathrm{mmol} \mathrm{l}^{-1}\right)$. They were on winter pasture (February) in an area where animals had died, probably from malnutrition, in previous years.

Hyvärinen et al. (1977) found that serum calcium was very low $\left(1.7 \mathrm{mmol} \mathrm{l}^{-1}\right)$ and serum magnesium moderately reduced in female reindeer living under very poor nutritional conditions, cases of death from malnutrition occurring in April. On the other hand, Ahman et al. (1986) found normal serum calcium levels in reindeer that were in poor condition during winter, whilst the serum magnesium average was very low $\left(0.41 \mathrm{mmol} \mathrm{l}^{-1}\right)$. The corresponding figure in animals regarded to be in a normal bodily condition was slightly higher $(0.58$ mmol $\mathrm{l}^{-1}$ ). Even though half of the animals in poor condition had plasma magnesium $<0.3$ mmol $1^{-1}$, no symptoms of tetany were seen.

Subnormal plasma magnesium concentrations were induced experimentally in reindeer calves by Bjarghov et al. (1976). The concentration of the mineral decreased from $1 \mathrm{mmol} \mathrm{l}^{-1}$ to around $0.4 \mathrm{mmol} \mathrm{l}^{-1}$ when lichen was provided as the only feed for $1 \frac{1}{2}$ months. There were no tetany symptoms, and a very moderate drop in plasma calcium was interpreted as an adaptation to a decrease in plasma proteins. The authors drew attention to the low levels of both calcium and magnesium in lichen, and recommended the use of plasma magnesium as an indicator of the nutritional status of reindeer.

The above mentioned studies indicate the excistence of more or less interrelated disturbances of the calcium and magnesium metabolism in reindeer on winter pastures. In the present study the occurrence of hypomagnesaemia was studied in 4 reindeer herds on winter pastures based on a large number of samples. Findings from correlation tests between plasma magnesium, calcium and inorganic phosphorus are reported. Comparison is made to evidence from the literature of disturbances in calcium homeostasis and the occurrence of hypocalcaemia in other species during magnesium deficiency. In addition, the relationships between plasma mineral values and other parameters, such as age of the animals and pregnancy status, were investigated.

\section{Materials and methods}

\section{Animals}

Blood samples were taken from female reindeer (Rangifer tarandus tarandus) in 2 herds in Finnmark county (Sørøy, n=325 and Magerøy, $\mathrm{n}=706$ ), during the winter season from 1992 until 1994 (Sørøy) and from 1992 until 1995 (Magerøy). All samples were collected in late January except those from Magerøy 1992, which were collected in early March. The herds had their summer pastures on 2 islands located on the northern coast of Finnmark $\left(72^{\circ} \mathrm{N}\right)$. The animal density on Magerøy was 10 reindeer per $\mathrm{km}^{2}$ as compared to 4 per $\mathrm{km}^{2}$ at Sørøy. Thus, 
greater competition for pasture resources on Magerøy could explain the lower autumn live body mass usually found in the autumn in the Magerøy herd compared to the Sørøy animals (unpublished results).

In the autumn, the Magerøy herd was made to swim from the island pasture to the mainland in mid-September, while the Sørøy animals were ferried to the mainland in the middle of October. The migration to the winter pastures in the central part of the Finnmark mountain plateau took about 1 to 2 months, both herds covering a distance of about $250 \mathrm{~km}$. During this migration, pasture quality varied considerably, but was generally regarded to be satisfactory. During winter the 2 herds were kept on adjacent pastures. The winter pasture was generally regarded to be of moderate quality, consisting predominantly of lichen.

Animals of varying age in a herd from the mountain districts of central southern Norway (Filefjell, $\mathrm{n}=391,62^{\circ} \mathrm{N}$ ) were blood sampled in January, 1995. The quality of both winter and summer pastures in this area was regarded to be good. The migration route from summer to winter pastures was approximately $60 \mathrm{~km}$.

In Lom, a neighbouring area to the north of Filefjell, young reindeer, all of the same age group (2-2 $1 / 2$ years old) were blood sampled in July $(n=56)$ and September $(n=51), 1991$, and in January $1992(n=67)$. The Lom animals were on very good pastures regarded to be among the best in the country. Also in Lom, lichens constitute a major part of the winter feed. Animals from this herd were included because they were assumed to represent a well managed herd living under optimal nutritional conditions. The analytical data from this herd were used as control data for comparison with that for animals living under more variable environmental conditions.

Most of the animals carried ear tags with an individual code indicating year of birth. Live body mass was recorded shortly after blood sampling in the Magerøy and Filefjell herds.

\section{Blood sampling}

Blood samples were collected when animals were corralled for slaughtering or counting. Groups of about 20 animals were taken from the large herd into smaller corals for sampling. The animals were caught and restrained. Jugular venous blood was drawn with heparinized vaccuum tubes (Venoject ${ }^{\circledR}$, Leuven, Belgium) within 2 minutes of capture and plasma was produced from fresh blood by centrifugation in the field (2000G , 15 minutes). Plasma was preferred because it was easier to produce than serum under outdoor sampling conditions. The plasma was stored at $-70^{\circ} \mathrm{C}$ until analysis.

\section{Plasma minerals}

Plasma minerals were analysed at the Central Laboratory, Norwegian College of Veterinary Medicine, Oslo. The minerals determined were magnesium $(\mathrm{Mg})$, calcium $(\mathrm{Ca})$ and inorganic phosphorus ( $\mathrm{P})$. The analyses were performed on a Technichon Axon ${ }^{\mathrm{TM}}$ System (Miles Inc., Diagnostic Division, Tarrytown, NY, USA). Plasma magnesium was analysed by an enzymatic method (UV), Sera Pak (Bayer, Germany). Plasma calcium and inorganic phosphorus were analysed by colorimetric methods utilising o-cresolphthalein complexone (Ca) and phosphomolybdate $(\mathrm{P})$, respectively. Reagents for both assays were manufactured by Technicon (Bayer Corp., Diagnostic Division, Tarrytown, NY, USA). Internal controls were assayed before and after each series of 30 samples. The control sera were Test Point ${ }^{\mathrm{TM}} 1$ and Test Point ${ }^{\mathrm{TM}} 2$ (Technicon Axon ${ }^{\circledR}$, Miles Inc., Diagnostic Division, Tarrytown, NY, USA) and Seronorm $^{\circledR}$ (Nycomed, Oslo, Norway).

In the discussion of the results suceptibility to hypocalceamia and hypomagnesaemia has been estimated by counting animals with plasma 


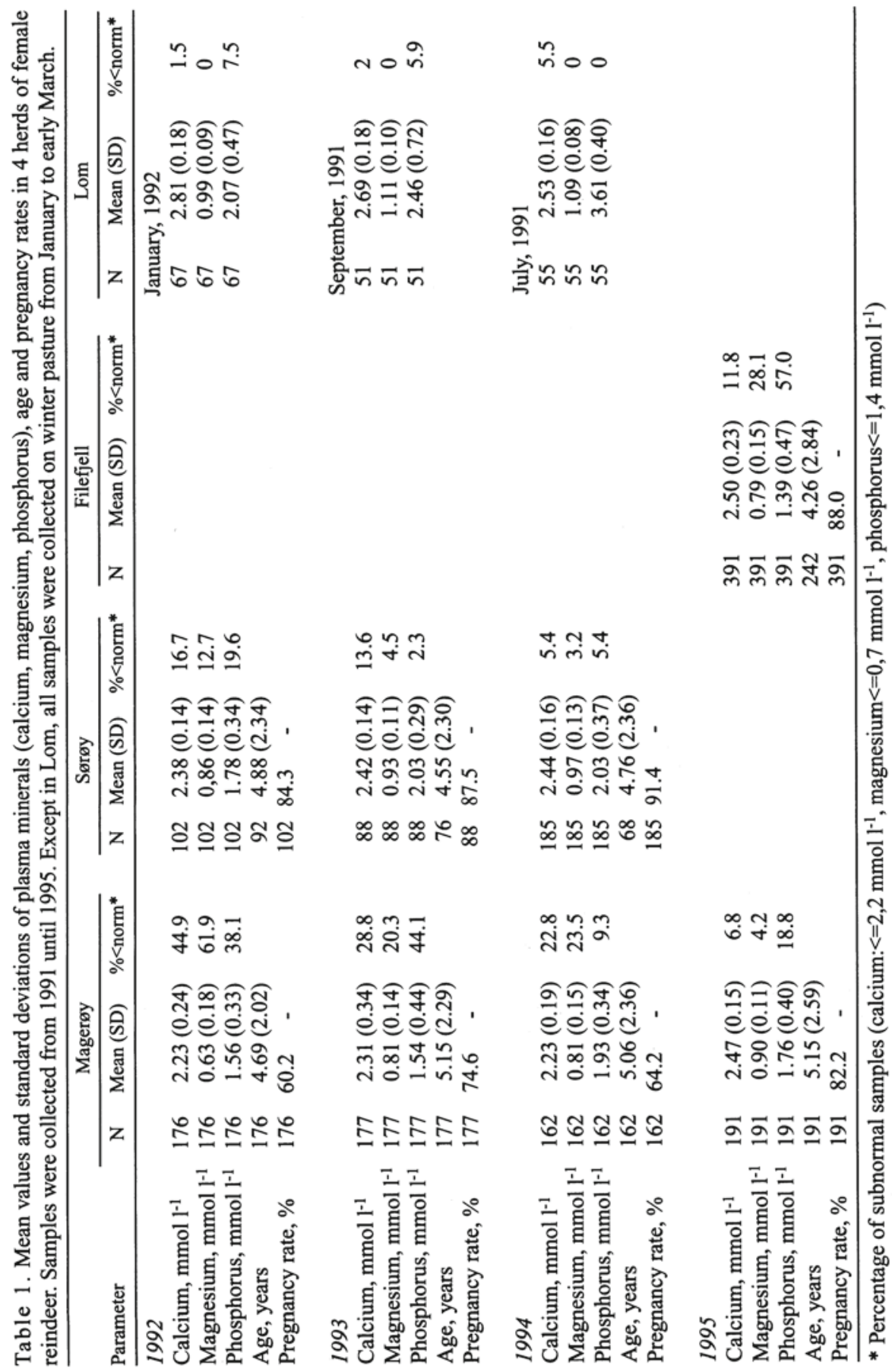



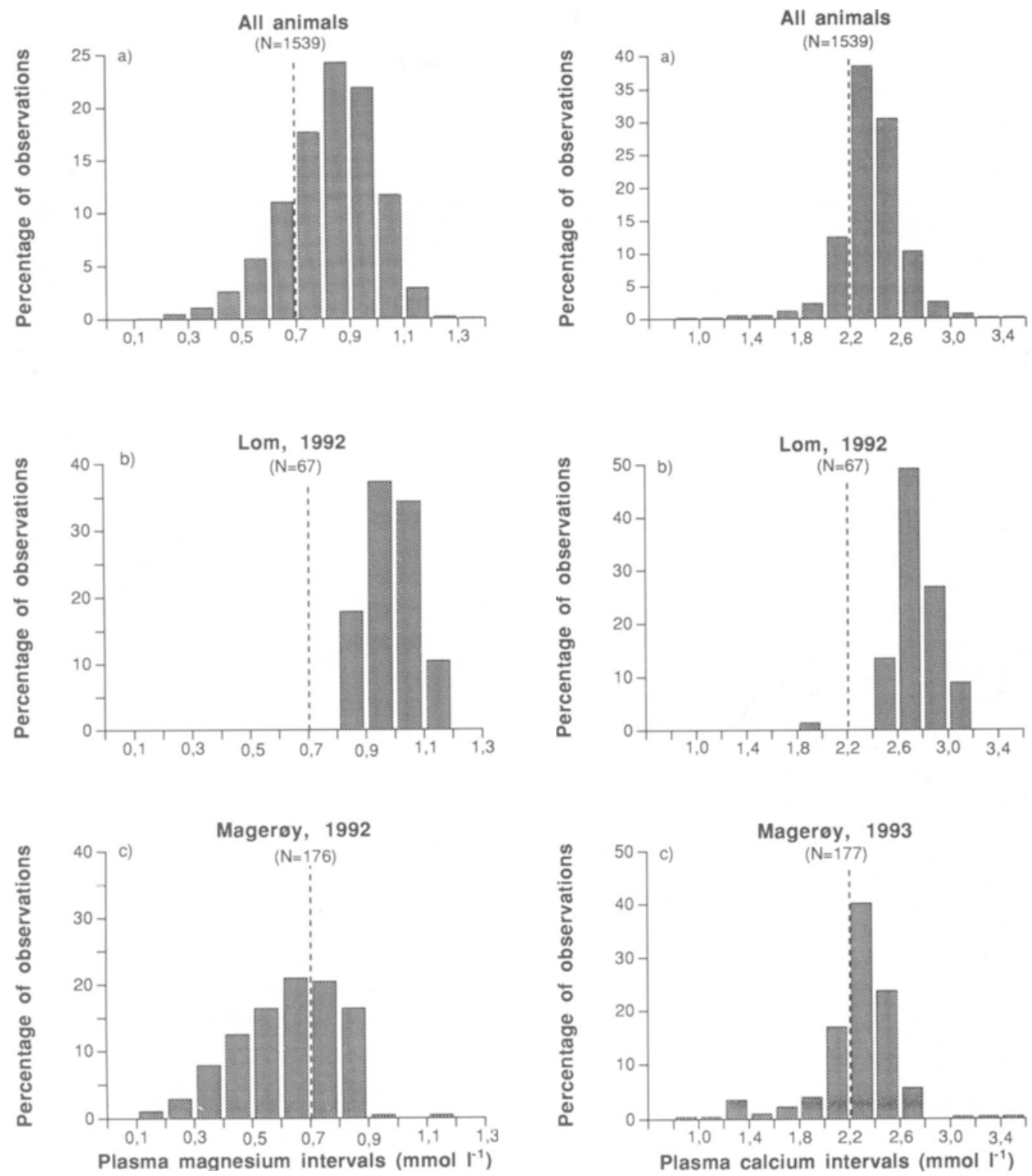

Figure 1. Frequency distribution (\%) of plasma magnesium concentrations in blood samples from female reindeer collected from 1992 until 1995 on winter pastures between January and early March. The frequency distribution of all animals (a) is compared with those in herds with normal (b) and low (c) levels. A lower normal limit of $0.7 \mathrm{mmol} \mathrm{1}^{-1}$ is indicated (broken lines).

Figure 2. Frequency distribution (\%) of plasma calcium concentrations in blood samples from female reindeer collected from 1992 through 1995 on winter pastures between January and early March. The frequency distribution of all animals (a) is compared with those in herds with normal (b) and low (c) levels. A lower normal limit of $2.2 \mathrm{mmol} \mathrm{l}^{-1}$ is indicated (broken lines). 

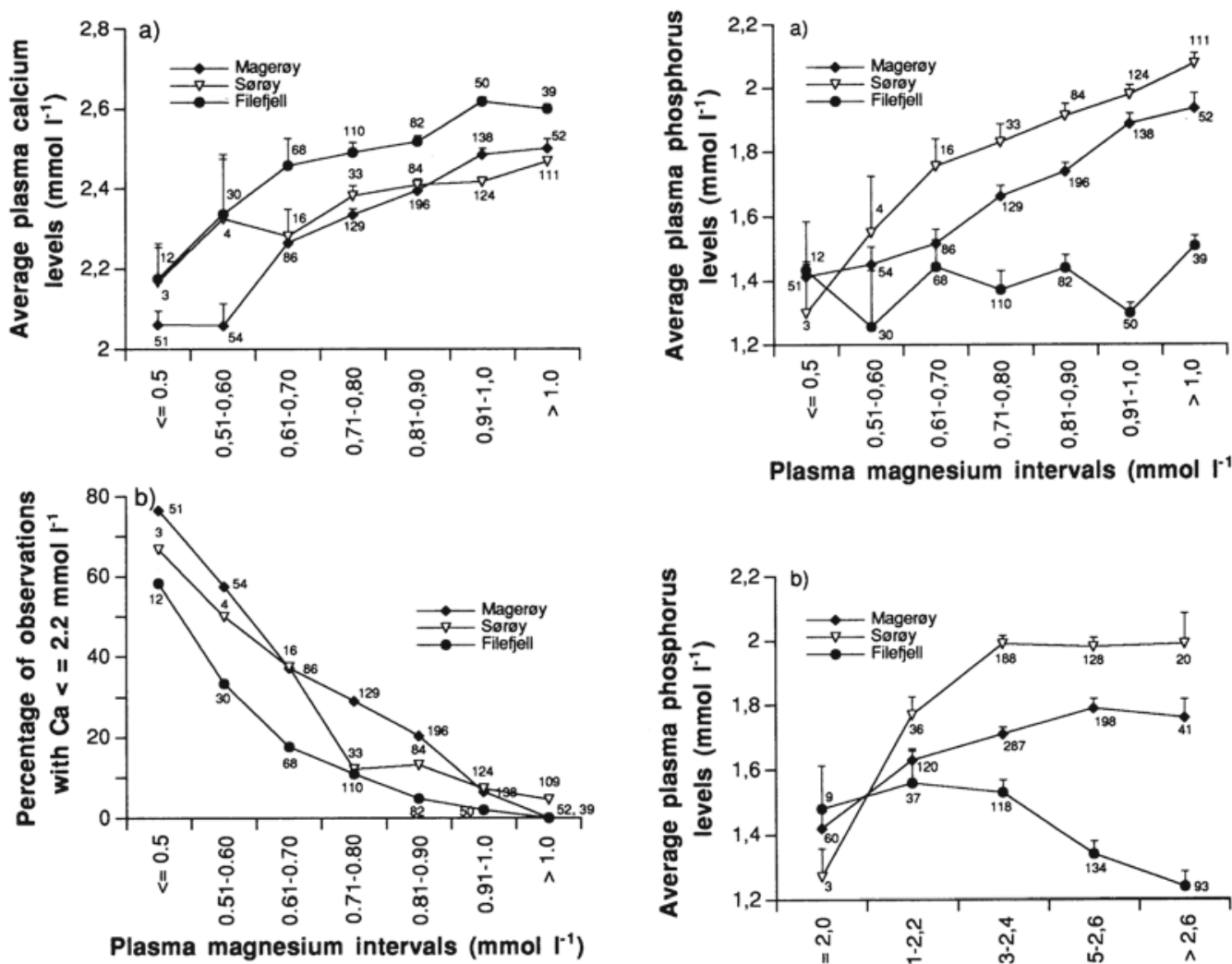

Plasma magnesium intervals ( $\mathrm{mmol} \mathrm{f}^{-1}$ )

Figure 3. Average calcium concentrations (a) and percentage of subnormal $\left(\leq 2.2 \mathrm{mmol} \mathrm{l}^{-1}\right)$ calcium concentrations (a) as related to magnesium concentrations (b). Magnesium values are grouped into seven concentration ranges. Numbers of observations within herd and magnesium range (total=1539) are indicated.

calcium values $\leq 2 \mathrm{mmo} \mathrm{l}^{-1}$ and plasma magnesium $\leq 0.7 \mathrm{mmol} \mathrm{l}^{-1}$ (Table 1, Figs. 1-4). These borderline values were chosen as approximations to renal threshold levels for the 2 elements for species with normal averages around 2.5 mmol $\mathrm{l}^{-1}$ for calcium and $1.0 \mathrm{mmol} \mathrm{l}^{-1}$ for magnesium in plasma (reindeer: Hyvärinen et al. 1977; Áhman et al. 1986). Reference is made to threshold estimates for calcium in cattle (Hove et al. 1983; Halse 1984) and for magnesium in

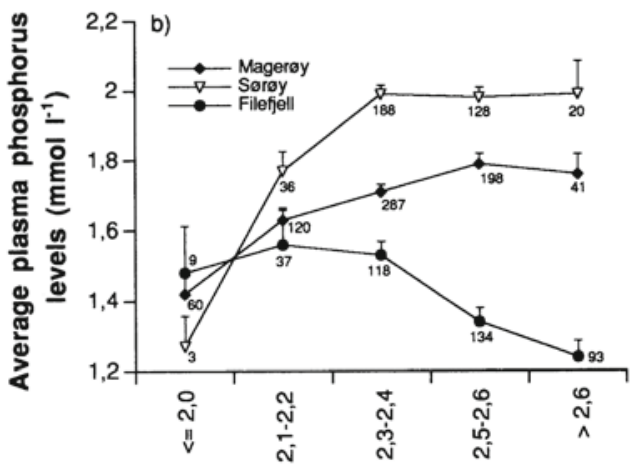

Plasma calcium intervals $\left(\mathrm{mmol} \mathrm{l}^{-1}\right)$

Figure 4. Average plasma phosphorus concentrations related to magnesium (a) and calcium (b) concentrations. Magnesium and calcium values were grouped into seven and five concentration ranges, respectively. Numbers of observations within herd and mineral range (total $=1539)$ are indicated.

reindeer (Halse et al. 1976), cattle (Ender et al. 1957) and rats (Averill \& Heaton 1966). Furthermore, in good agreement with these authors the lower limit of a statistically determined normal plasma magnesium range has been found to be $0.75 \mathrm{mmol} \mathrm{l}^{-1}$ both in cattle (Allcroft \& Green 1934) and in man (Elin 1988). The term hypomagnesaemia was used by Blaxter et al. (1954) when plasma magnesium was $\leq 0.7$ $\mathrm{mmol} \mathrm{l}^{-1}$ (hypomagnesaemic tetany $<0.4 \mathrm{mmol}$ 
Table 2. Least squares means for plasma minerals (calcium, magnesium and phosphorus) in female reindeer by herd, year of sampling, pregnancy status, and age group. Least squares means with different superscript differ significantly $(\mathrm{p}<0.05)$. The level of significance for each variable used in the models is indicated.

\begin{tabular}{|c|c|c|c|c|}
\hline \multirow[b]{2}{*}{ Parameter } & \multirow[b]{2}{*}{ Category } & \multicolumn{3}{|c|}{ Least squares means, $\mathrm{mmol} / \mathrm{l}$} \\
\hline & & $\overline{\text { Calcium }}$ & Magnesium & Phosphorus \\
\hline \multicolumn{5}{|l|}{ Flock } \\
\hline & Magerøy & $2.34^{\mathrm{a}}$ & $0.8^{\mathrm{a}}$ & $1.73^{\mathrm{a}}$ \\
\hline & Sørøy & $2.34^{\mathrm{a}}$ & $0.91^{\mathrm{b}}$ & $1.86^{\mathrm{b}}$ \\
\hline & Filefjell & $2.41^{\mathrm{b}}$ & $0.71^{\mathrm{c}}$ & $1.44^{\mathrm{c}}$ \\
\hline \multicolumn{5}{|l|}{ Year } \\
\hline & 1992 & $2.35^{\mathrm{a}}$ & $0.71^{\mathrm{a}}$ & $1.62^{\mathrm{ab}}$ \\
\hline & 1993 & $2.33^{\mathrm{a}}$ & $0.83^{b}$ & $1.59^{\mathrm{b}}$ \\
\hline & 1994 & $2.35^{\mathrm{a}}$ & $0.81^{b}$ & $1.82^{\mathrm{c}}$ \\
\hline & 1995 & $2.42^{b}$ & $0.88^{\mathrm{c}}$ & $1.67^{\mathrm{a}}$ \\
\hline \multicolumn{5}{|c|}{ Pregnancy status } \\
\hline & Pregnant & $2.4^{\mathrm{a}}$ & $0.82^{\mathrm{a}}$ & 1.66 \\
\hline & Barren & $2.33^{\mathrm{b}}$ & $0.79^{b}$ & 1.69 \\
\hline \multicolumn{5}{|c|}{ Age Group } \\
\hline & $>2$ years & $2.34^{\mathrm{a}}$ & 0.8 & 1.67 \\
\hline & 2-9 years & $2.39 \mathrm{~b}$ & 0.81 & 1.68 \\
\hline & $>9$ years & $2.35^{\mathrm{a}}$ & 0.81 & 1.67 \\
\hline \multicolumn{2}{|c|}{ Significance tests } & \multicolumn{3}{|c|}{ Level of significance, $(p)$} \\
\hline \multicolumn{2}{|l|}{ Flock } & $<0.01$ & $<0.001$ & $<0.001$ \\
\hline \multicolumn{2}{|l|}{ Year } & $<0.001$ & $<0.001$ & $<0.001$ \\
\hline \multicolumn{2}{|c|}{ Pregnancy status } & $<0.001$ & $<0.01$ & n.s. \\
\hline \multicolumn{2}{|l|}{ Age group } & $<0.001$ & n.s. & n.s. \\
\hline \multicolumn{2}{|l|}{ Calcium } & - & $<0.001$ & n.s. \\
\hline \multicolumn{2}{|c|}{ Magnesium } & $<0.001$ & - & $<0.001$ \\
\hline \multicolumn{2}{|c|}{ Phosphorus } & n.s. & $<0.001$ & - \\
\hline \multicolumn{2}{|l|}{$\mathrm{R}^{2}$-Model } & 0.3 & 0.44 & 0.29 \\
\hline
\end{tabular}

$\mathrm{l}^{-1}$ ) in bovine calves. Evidently, the classification of analytical findings in relation to threshold levels permits the identification of animals with low rates of excretion of minerals with the urine and a mineral-sparing adaptation of homeostatic mechanisms.

\section{Progesterone}

Plasma progesterone was measured by ELISA- kits utilising an enhanced chemiluminescense technique (Amerlite ${ }^{\circledR}$, Kodak Clinical Diagnostics, Amersham, UK). The assay was validated with reindeer plasma by demonstrating parallelism between dilutions of plasma samples and the standard curve. The detection limit of the assay was $0.2 \mathrm{nmol} \mathrm{l}^{-1}$. The intraassay coefficient of variation was $8.3 \%$ in the concentration range 1.9- $158 \mathrm{nmol} \mathrm{l}^{-1}$. The interassay coefficient of variation was $6.5 \%$ for samples in the concentration range between 14.8 and 47.8 nmol $1^{-1}$.

Plasma progesterone was used as a pregnancy test. Based on simultaneous measurements of plasma progesterone and rectal ultrasonographic investigation of the uterus, a discriminatory level of $7 \mathrm{nmol} \mathrm{1-1}$ was chosen to indicate pregnancy (unpublished results).

\section{Statistical analyses}

Statistical analyses were performed using SAS (1988) software programmes. The General Linear Models procedure was used. For the investigated minerals $(\mathrm{Ca}, \mathrm{Mg}$ and $\mathrm{P})$ the models included effects of year of sampling, herd, pregnancy status, age and mineral status. Three age groups were defined: yearlings, adults and old animals ( $>9$ years of age). Lom-animals were excluded from the analysis of variance. The variance contribution was calculated for independent variables from its sum of squares (SS; Type III) divided by total SS.

Correlation and linear regression analyses were used to assess relationships between mineral parameters.

\section{Results}

Average levels of plasma minerals varied between herds and year of sampling (Tables 1 and 2; Figs. 1 and 2). The overall average (SD; min-max) concentrations of plasma $\mathrm{Ca}, \mathrm{Mg}$ and $\mathrm{P}$ in samples collected on winter pastures were $2.42(0.25 ; 0.9-3.6), 0.83(0.17 ; 0.16-1.39)$ and 
Table 3. Correlation coefficients for the levels of plasma magnesium, calcium and inorganic phosphorus in 4 herds of female reindeer. The samples were collected on winter pasture between January and early March, from 1992 through 1995.

\begin{tabular}{lllccr}
\hline \multirow{2}{*}{ Flock } & $\mathrm{N}$ & \multicolumn{3}{c}{ Correlation matrix } & \multicolumn{1}{c}{ P } \\
\cline { 3 - 5 } Magerøy & 706 & Parameter & Magnesium & Phosphorus & $<0.0001$ \\
& & Calcium & 0.53 & 0.28 & $<0.0101$ \\
Sørøy & \multirow{2}{*}{375} & Magnesium & & 0.37 & $<0.0001$ \\
& & Calcium & 0.31 & 0.19 & $<0.0002$ \\
Filefjell & \multirow{2}{*}{391} & Magnesium & & 0.29 & $<0.0001$ \\
& & Calcium & 0.37 & -0.25 & n.s. \\
Lom & \multirow{2}{*}{67} & Magnesium & & 0.06 & n.s. \\
& & Calcium & 0.08 & 0.06 & n.s. \\
\hline All & 1539 & Magnesium & & 0.08 & $<0.001$ \\
& & Calcium & 0.45 & 0.09 & $<0.0001$ \\
\hline
\end{tabular}

$1.70(0,47 ; 0.2-3.4) \mathrm{mmol} 1-1$, respectively. The overall pregnancy rate was $79.8 \%$.

\section{Magnesium}

As shown in Table 1 , hypomagnesaemia $(\mathrm{Mg}$ $\geq 0.7 \mathrm{mmol} \mathrm{l}^{-1}$ ) was detected in 3 out of 4 herds. The lowest average magnesium concentration $\left(0.63 \mathrm{mmol} \mathrm{l}^{-1}\right)$ was found in 1992 among Magerøy-animals (Table 1). That year $61.9 \%$ of the samples showed $\mathrm{Mg}$ concentrations $\leq 0.70$ mmol $\mathrm{l}^{-1}$ (Fig. 1c). The magnesium status in Magerøy and Sørøy animals gradually improved from 1992 until 1994/1995 (Table 1). In Lom animals average levels around $1.0 \mathrm{mmol}$ $1^{-1}$ were found at 3 different times of year (Table 1; Fig. 1b). The Filefjell herd had the second lowest magnesium average (SD) of $0.79 \mathrm{mmol}$ $\mathrm{l}^{-1}(0.15)$ and a frequency of low magnesium values as high as $28.1 \%$ (Table 1 ).

A total of 26 samples (1.7\%) 21 of which were from the 1992 Magerøy material, had magnesium concentrations $\leq 0.4 \mathrm{mmol} \mathrm{l}^{-1}$. Altogether 273 samples (19.4\%), contained magnesium in the range from $0.4-0.7 \mathrm{mmol} \mathrm{1}^{-1}$.

\section{Calcium}

The frequency distribution patterns for calcium were generally narrower than for the other minerals (Figs. 1-2). As was the case for magnesium, the lowest herd calcium average was found in the 1992 Magerøy material (mean = $2.23 \mathrm{mmol} \mathrm{1}^{-1}$; Table 1). Altogether $79(44.9 \%)$

Table 4. Mean plasma mineral values (SD) and ranges in samples with herd minima for magnesium and calcium, respectively.

\begin{tabular}{|c|c|c|c|c|c|c|}
\hline Flock & Year & Category & $\mathrm{N}$ & $\begin{array}{l}\text { Calcium, mmol l-1 } \\
\text { Mean (SD) } \\
\text { Min - Max }\end{array}$ & $\begin{array}{c}\text { Magnesium, mmol l-1 } \\
\text { Mean (SD) } \\
\text { Min - Max }\end{array}$ & $\begin{array}{l}\text { Phosphorus, mmol l-1 } \\
\text { Mean (SD) } \\
\text { Min - Max }\end{array}$ \\
\hline Magerøy & 1992 & Low Mg & 7 & $\begin{array}{l}1.89(0.4) \\
1.2-2.3\end{array}$ & $\begin{array}{l}0.23(0.04) \\
0.16-0.27\end{array}$ & $\begin{array}{c}1.3(0.26) \\
0.9-1.6\end{array}$ \\
\hline Magerøy & 1993 & Low Ca & 9 & $\begin{array}{c}1.3(0.19) \\
0.9-1.6\end{array}$ & $\begin{array}{l}0.57(0.05) \\
0.52-0.66\end{array}$ & $\begin{array}{c}0.85(0.28) \\
0.4-1.3\end{array}$ \\
\hline
\end{tabular}


samples from this herd contained calcium levels of $\leq 2.2 \mathrm{mmol} \mathrm{l}^{-1}$, extremely low calcium concentrations $\left(<1.8 \mathrm{mmol} \mathrm{l}^{-1}\right)$ being found in 17 samples $(9.7 \%)$. A majority of these $(n=10)$ were from 1993. In the other herds, plasma concentrations of $\leq 2.0 \mathrm{mmol} \mathrm{l}^{-1}$ were rarely found. The high calcium averages in Lom animals (Table 1) can be illustrated by the fact that in only one winter sample from this herd was a level of $\leq 2.2 \mathrm{mmol} \mathrm{l}^{-1}$ measured (Fig. 2b).

\section{Phosphorus}

Average plasma phosphorus levels were highest in the Lom animals and lowest in the Filefjell animals (Table 1). In the latter herd a total of 223 (57\%) samples had phosphorus concentrations $\leq 1.4 \mathrm{mmol} \mathrm{l}^{-1}$. Generally, phosphorus concentrations showed greater standard deviations than the two other minerals within as well as between herds (Table 1).

\section{Mineral interrelationships}

Significant positive correlations between plasma calcium and magnesium (Table 3) were found in the 3 herds where hypomagnesaemia $(\mathrm{Mg} \leq 0.7)$ was detected (Table 1$)$. The regression curves for the affected herds (Fig. 3a) show a mean decline in calcium of about $15 \%$ associated with a decrease in magnesium from 1 to $<0.5 \mathrm{mmol} \mathrm{l}^{-1}$. In the magnesium range $>0.6$ mmol $1^{-1}$ Magerøy and Sørøy animals gave nearly identical calcium averages which were consistently about $0.15 \mathrm{mmol} \mathrm{l}^{-1}$ below corresponding levels in the Filefjell herd. The reproducibility within herds of a common pattern of magnesium-related calcium variations is further illustrated by the subnormal calcium values $\left(\leq 2.2 \mathrm{mmol} \mathrm{l}^{-1}\right)$ which increased gradually to $60 \%-78 \%$ when magnesium decreased to $<0.5 \mathrm{mmol} \mathrm{l}^{-1}$. Pooled observations from the 3 herds in the same figure showed that the lowcalcium frequency increased significantly $(\mathrm{p}<0.02)$ to $15.2 \%$ at moderately reduced mag- nesium levels $\left(0.7-0.8 \mathrm{mmol} \mathrm{l}^{-1}\right)$ compared to $4.5 \%$ in the magnesium range $>0.9 \mathrm{mmo}^{-1}$. When tested together with the independent variables listed in Table 2, plasma magnesium gave a contribution as high as $12.2 \%$ to the variance of calcium. Conversely, the effect of calcium on magnesium variance was $9.7 \%$.

Table 4 shows, respectively, calcium and phosphorus levels corresponding to extremely low magnesium values (Magerøy 1992) and magnesium and phosphorus levels in animals with minimal calcium levels (Magerøy 1993). Contrary to the correlation tests in Table 3, the calcium and magnesium values appear inversely related. Very low phosphorus levels $(\mathrm{p}<0.05)$ were found in the lowest calcium category.

In general, the correlation between magnesium and phosphorus was stronger than that between calcium and phosphorus (Table 3, Fig 4). Almost identical positive correlation coefficients were found in successive years in the Magerøy herd. In contrast, phosphorus was unrelated to magnesium in the Filefjell herd (Table 3; Fig. 4a). In spite of varying within-year correlation coefficients, the pooled Sørøy-material gave a positive regression curve for phosphorus against magnesium, similar to that for Magerøy (Fig. 4a; Table 3). The tests for calcium / phosphorus interrelationships gave inconsistent results, the 2 minerals appearing alternatively positively $(r=0.28)$ and negatively $(r=-0.25)$ correlated in different groups of animals (Table 3).

According to Table 3 magnesium and inorganic phosphorus were significantly positively correlated in the Magerøy and Sørøy herds. Nearly linear magnesium-related phoshorus increments were observed both in the hypomagnesaemic $\left(\leq 0.7 \mathrm{mmol} \mathrm{l}^{-1}\right)$ and the normal magnesium range (Fig. 4a). In cattle an apparent phosphorus-depressant effect of moderate decreases in magnesium was found to be statistically significant $(\mathrm{p}<0.001)$ for these 2 herds by 


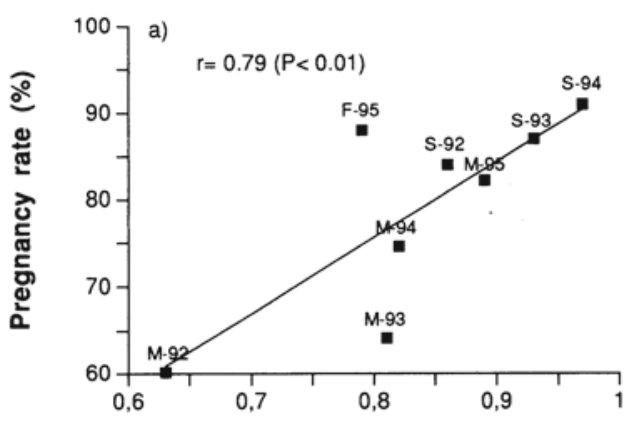

Average plasma magnesium levels $\left(\mathrm{mmol} \mathrm{l}^{-1}\right)$

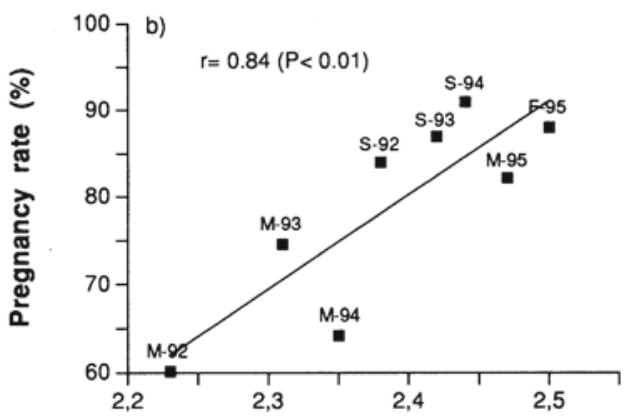

Average plasma calcium levels $\left(\mathrm{mmol} \mathrm{l}^{-1}\right)$

Figure 5. Pregnancy rate within herd and year as a function of average plkasma magnesium (a) and calcium (b) concentrations. Identification of herd and of year of sampling are given in abbreviated form (M=Magerøy; $\mathrm{S}=$ Sørøy; $\mathrm{F}=$ Filefjell; $-92=1992$ etc.)

comparing the frequencies of low phosphorus values $\left(\leq 1.4 \mathrm{mmol} \mathrm{l}^{-1}\right)$ in the magnesium ranges 0.81-0.9 and >0.9, respectively Kaneko (1989). The 2 variables appeared unrelated in the third herd with hypomagnesaemia (Filefjell, Table 3, Fig. 4a).

A curved regression for inorganic phosphorus and calcium (Fig. 4b) can explain a lower correlation coefficient for these 2 parameters than between magnesium and phosphorus (Table 3 ). Above the renal calcium threshold $(>2.2 \mathrm{mmol}$ $\left.1^{-1}\right)$ phosphorus either remained unaffected by calcium ( 2 herds) or showed a decrease with increasing calcium levels (Filefjell; Fig. 4b). However, at subthreshold levels, phosphorus averages decreased together with calcium consistently to $<1.5 \mathrm{mmol} \mathrm{l}^{-1}$ in all 3 herds.

\section{Pregnancy}

Pregnant animals had significantly $(\mathrm{p}<0.01)$ higher plasma magnesium and calcium least squares means than barren females (Table 2). Similarly, a significant relationship was found between pregnancy rate and average concentrations of the same minerals (Fig. 5). The coefficients of correlation between mineral averages and pregnancy rate were 0.79 and 0.84 for magnesium and calcium, respectively $(\mathrm{p}<0.01)$. Average phosphorus concentration was not significantly related to pregnancy rate.

Age

Adult females had slightly higher $(\mathrm{p}<0.05)$ plasma calcium least squares means than yearlings and old females. Magnesium and phosphorus concentrations were not influenced by age group (Table 2).

\section{Discussion}

It is difficult to specify environmental factors as the causes of significant (Table 2) differences in plasma minerals between groups in Table 1 . Differences in the availability of dietary minerals could be the reason why the Magerøy herd gave consistently lower mineral averages than the Sørøy animals (Tables 1 and 2) for 3 years. The significance of year on all 3 minerals (Table 2) could be due to climatic variations affecting the well-being of the animals. Direct comparison of averages in Table 1 futher suggests that the Filefjell herd was better supplied with calcium than with magnesium, while the Lom diet apparently was well balanced with respect to both elements. As controls the Lom samples 
are of interest (Table 1), since it appears that reindeer can survive on frozen winter pastures without the susceptibility to hypocalceamia and hypomagesaemia seen in the other herds.

The finding of significantly higher calcium and magnesium values in pregnant than in barren animals (Table 2) was unexpected. Possibly, fecundity can be influenced by subtle variations in mineral metabolism. It would be of interest to compare the present findings with measurements towards the end of the gestation period when the demands for minerals is at a maximum.

Seemingly, plasma calcium was better maintained in middle-aged than in young and old animals (Table 2). Logically, the finding reflects age-dependent variations in the ability to tolerate the stresses on mid-winter pastures. It is of interest that the positive correlation between calcium and magnesium in other tests (Table 3 ) was influenced by age-dependent magnesium variations (Table 2).

The nature of the relationship between calcium and magnesium is illustrated by the within herd correlation tests (Table 3). Seemingly, the correlation coefficient increased with the frequencies of subnormal magnesium concentrations given in Table 1. Actually, the correlation was not significant in the Lom-herd where all magnesium values were within a range considered to be normal.

According to Table 1 and Fig 1b, in only the Lom herd were magnesium values consistently normal (minimum $0.83 \mathrm{mmol} \mathrm{l}^{-1}$ ). In the 3 other herds, cases of hypomagnesaemia were detected even in years when herd averages for magnesium were above $0.9 \mathrm{mmol} \mathrm{l}^{-1}$. The exceptionally high frequency of hypomagnesaemia in Magerøy in 1992 (Fig 1c) may partly be a seasonal effect since the actual sampling month was March as against January for the rest of the material. A frequency of subnormal magnesium concentrations as high as $28.1 \%$ in the Filefjell herd is of special interest, since it shows that hypomagnesaemia on winter pastures may be a problem which is not necessarily limited to animals exposed to extreme environmental conditions such as those prevailing in northern Norway.

Quite severe, long-lasting hypomagnesaemia has been reported frequently in cattle not showing signs of tetany (review: Hemingway \& Ritchie, 1965). Of special interest in the context of the present study are the findings of Allcroft et al. (1938) in a large herd of cows which was managed in much the same way as Norwegian reindeer, at a ranch in southern England. The "semi-wild" beef animals were kept at pasture all the year around. Without showing signs of tetany the cows had December magnesium minima which were comparable to those found among the Magerøy reindeer in 1992. At the time, grass growth was at its poorest and the cows were non-lactating and in mid-gestation. When not in lactation, reindeer, like cattle can apparently remain in a subclinical condition with plasma magnesium levels well below 0.7 $\mathrm{mmol} \mathrm{l}^{-1}$. The reduction of plasma mineral concentrations to below renal threshold concentrations in the winter can thus be looked upon as a strategy for survival in periods of deficient mineral feeding. It should, however, not be forgotten that grass tetany in cattle is a lactation disease. Therefore, it is logical to assume that the susceptibility to such disorders is at a maximum in the spring calving season when the homeostatic mechanisms are stressed by utilisation of body minerals for milk production.

A positive relationship between plasma calcium and magnesium (Table 1 and 2; Fig. 3 ) is consistent with the demonstration in many species of susceptibility to hypocalcaemia in hypomagnesaemic animals (Anast \& Forte, 1983). In cattle (Hemmingway \& Ritchie 1965) and in humans (Shils 1969) an effect of magnesium on calcium metabolism is evidenced by the fact 
that low calcium levels can be normalised by magnesium supplementation. According to Reinhart (1988), postulated causal mechanisms by which calcium homeostasis can be disturbed by a magnesium deficiency are controversial. Effects of magnesium on parathyroid hormone and calcitriol $\left(1,25-(\mathrm{OH})_{2}\right.$-vit $\left.\mathrm{D}_{3}\right)$ and direct magnesium effects on bone metabolism are discussed in the literature.

The evidence of hormonal involvement referred to does not preclude variations in the severity of hypomagnesaemic hypocalcaemia related to the level of dietary calcium. Thus, it is possible that higher calcium averages in the Filefell herd than in other herds at identical magnesium concentrations (Fig. 3) can be due to differences in the supply of minerals. Botanical diversity and the level of competition between animals for pasture resources may be important sources of variation in this respect.

Fig. 3 shows that the frequency of animals with seemingly magnesium-related decreases in calcium began to increase as soon as magnesium levels fell below $0.8-0.9 \mathrm{mmol} \mathrm{l}^{-1}$. Analogies to this apparent magnesium sensitivity are found in the literature. Contreras et al. (1982) reported a $35 \%$ decrease in the rate of calcium mobilisation in bulls and dairy cows on a magnesium deficient diet which lead to a drop in plasma magnesium from $0.9-1.0 \mathrm{mmol} \mathrm{l}^{-1}$ to, respectively, 0.72 and $0.54 \mathrm{mmol} \mathrm{l}^{-1}$. And in diabetic children an increase in plasma calcium from 2.12 to $2.39 \mathrm{mmol} \mathrm{l}^{-1}$ was found when the magnesium level increased from 0.67 to 0.86 $\mathrm{mmol} \mathrm{l}^{-1}$ as a result of dietary magnesium supplementation (Saggese et al. 1991). The effect of such supplementation on plasma levels of the 2 minerals was accompanied by a $30-40 \%$ increase in plasma parathyroid hormone and calcitriol.

In discussing the correlation between calcium and magnesium it should be borne in mind that the 2 minerals may also vary inversely, as is the case in hypocalcaemic periparturient dairy cows and in cows in which hypercalcaemia is induced with calcitriol and related compounds (Hove et al. 1983, Moate et al. 1987). An explanation could be competition for some common transport mechanism, for instance in the kidneys (rats: Quamme, 1982; dairy cows: Halse, 1984). Actually, the severity of the hypocalcaemia in reindeer can be inversely related to the decrease in magnesium, as shown by the averages from different years in Table 4. Similar differences in the magnesium/calcium ratio are found by comparing mineral measurements from different reindeer studies referred to (see: Introduction). Plasma magnesium may be an inaccurate indicator of the severity of a magnesium deficiency when plasma calcium levels are low. As an example, reference is made to Bohman et al. (1983) who observed a transient increment in plasma magnesium in hypomagnesaemic dairy cows when they developed hypocalcaemia and tetany.

Adaptation to hypoproteinaemia may have contributed to the variability of plasma calcium in the present study. It should be noted, however, that the hypocalcaemic reindeer studied by Hoff et al. (1993) had normal plasma protein levels. In future studies, measurement of plasma potassium may contribute to a better understanding of the metabolic relationships between minerals, since hypokalaemia has been observed during experimental hypomagnesaemia both in reindeer calves (Bjarghov et al. 1976) and in human volunteers (Shils 1969). The finding of interest is that plasma potassium levels also return to normal together with calcium levels, as a result of replenishment with magnesium (Shils 1969).

Variations in plasma inorganic phosphorus are difficult to interpret since the parameter is influenced both by variations in mineral metabolism and the metabolism of carbohydrates and energy. As far as we know, a normal concentra- 
tion range has not been established for reindeer. Consequently, for the discussion of the present results, a lower normal limit corresponding to findings for domestic ruminants $\left(1.4 \mathrm{mmol} \mathrm{l}^{-1}\right)$ was used (Kaneko 1989).

Measurements by Karns \& Crichton (1978) indicate that plasma inorganic phosphorus levels in reindeer are more sensitive than plasma calcium and magnesium to the stresses of capturing and blood sampling. Stress effects may thus explain some of the variability of the findings with regard to phosphorus, and to some extent the seemingly erratic behaviour of this component in the present study (Table 3).

The reproducibility of a positive relationship between phosphorus and magnesium is evidenced by measurements from 4 and 3 successive years in the Magerøy and Sørøy herds (Table 3, Fig. 4a). The absence of magnesium related variations in phosphorus in the Filefjell herd (Fig 4a) is therefore somewhat enigmatic. This latter finding may possibly reflect differences in mineral nutrition, since Filefjell animals distinguished themselves by showing higher plasma calcium levels than the Magerøy and Sørøy animals (Fig 3).

Low plasma phosphorus in severely hypocalcaemic animals (Table 4) could be due to increased parathyroid hormone secretion. Variable parathyroid inhibition by hypomagnesaemia at moderately decreased calcium levels could be the reason why the correlation tests of inorganic phosphorus against calcium gave inconsistent results (Table 3 ). In the discussion of the multiple factors believed to be involved when calcium homeostasis is influenced by magnesium, it has been maintained that a low level of plasma magnesium can both inhibit and stimulate parathyroid hormone secretion (Ebel \& Günther 1980), dependent on the severity of the hypomagnesaemia (Anast \& Forte 1983). It has been suggested recently that the affinity for calcium of inhibitory receptors in the parathy- roids increases when plasma magnesium is low (Mori et al. 1992). In further studies of hypomagnesaemia in reindeer levels of parathyroid hormone and other calcium-regulating hormones should therefore be determined.

In the Scandinavian studies mentioned previously (Áhman et al. 1986, Hyvärinen et al. 1977 and Hoff et al. 1993) the severely hypomagnesaemic and/or hypocalcaemic animals were evidently in a poor condition. It is likely that poor nutrition also played a role in the development of hypomagnesaemia also in the herds investigated in the present study, but no systematic recording of live body mass was performed. The highly significant relationships between pregnancy rate and herd averages of calcium and magnesium (Fig. 5) should be interpreted with care. Further studies are needed to determine the effects of mineral status at different stages of the reproductive cycle on fecundity in reindeer.

In conclusion, reindeer are likely to suffer from mineral deficiencies during winter although great variations in mineral concentrations can be found between herds and year of sampling. The practical importance of such imbalances in terms of health, fecundity and possible production losses needs further evaluation. Significant interrelationships were found between minerals, particularly between calcium and magnesium. The results indicated that calcium homeostasis was sensitive to changes in blood magnesium concentrations.

\section{Acknowledgements}

We wish to thank H. Hansen and K. Frøslie for excellent technical assistance. The project was financed by Reindriftens Fagråd.

\section{References}

Allcroft WM., Green HM: Blood calcium and magnesium of the cow in health and disease. Biochem. J. 1934, 28, 2220-2228. 
Allcroft WM, Green HM: Seasonal hyomagnesaemia of the bovine, without clinical symptoms. J. Comp. Pathol. Therap. 1938, 51, 176-191.

Anast CS, Forte LF: Parathyroid function and magnesium depletion in the rat. Endocrinology 1983, 113, 184-189.

Averill CM, Heaton FW: The renal handling of magnesium. Clin. Sci., 1966, 31, 353-360.

Bjarghov RS, Fjellheim P, Hove $K$, Jacobsen E, Skjenneberg $S$, Try $K$ : Nutritional effects on serum enzymes and other blood constituents in reindeer calves (Rangifer tarandus tarandus). Comp. Biochem. Physiol. 1976, 55A, 187-193.

Blaxter KL, Rook JAF, MacDonald AM: Experimental magnesium deficiency in calves. 1 Clinical and pathological observations. 2 The metabolism of calcium, magnesium and nitrogen and magnesium requirements. J. Comp. Path. 1954, 64, 157175, 176-186.

Bohman VR, Horn FP, Littledike ET, Hurst JG, Griffin $D$ : Wheat pasture poisoning II. Tissue composition of cattle grazing cereal forages as related to tetany. J. Anim. Sci. 1983, 57, 1364-1373.

Contreras PA, Manston R, Sansom BF : Calcium mobilisation in hypomagnesaemic cattle. Res. Vet. Sci. 1982, 33, 10-16.

Ebel H, Günther T: Magnesium metabolism: A review. J. Clin. Chem. Clim. Biochem. 1980, 18, 257-270.

Elin RH: Magnesium metabolism in health and disease. Dis. Mon. 1988, 34, 163-218.

Ender F, Dishington JW, Helgebostad A, Martisons $E$ : The magnesium problem in relation to the tetany paresis syndrome in dairy cows. Nord. Vet. Med., 1957, 9, 881-917.

Halse $K$ : Calcium effects on renal conservation of magnesium in cows. Acta. vet. scand. 1984, 25, 213-228.

Halse K, Skjenneberg S, Jacobsen E, Bjarghov RS: Blood magnesium and the renal magnesium threshold in lichen-fed and fasted reindeer. Nord. Vet.Med. 1976, 28, 529-538.

Hemingway RG, Ritchie NS: The importance of hypocalcaemia in the development of hypomagnesaemic tetany. Proc. Nutr. Soc. 1965, 24, 54-63.

Hoff B, Rognmo A, Havre G, Morberg H: Seasonal hypomagnesaemia in reindeer on Kautokeino winter pasture in Finnmark County, Norway. Rangifer 1993, 13, 133-136.

Hove $K$, Horst RL, Littledike ET: Effects of $1 \alpha$-hydroxyvitamin $\mathrm{D}_{3}, 1,25$-dihydroxyvitamin $\mathrm{D}_{2}$,
1,24,25 (-trihydroxyvitamin $\mathrm{D}_{3}$ and 1,25,26 trihydroxyvitamin $\mathrm{D}_{3}$ on mineral metabolism and 1,25 dihydroxyvitamin D3 concentration in dairy cows. J. Dairy. Sci. 1983, 66, 59-66.

Hyvärinen $H$, Helle $T$, Nieminen $M$, Väyrynen $P$, Väyrynen $R$ : The influence of nutrition and seasonal conditions on mineral status in the reindeer. Can. J. Zool. 1977, 55, 648-655.

Kaneko JJ: Clinical Biochemistry of Domestic Animals 1989, 888 -891. Academic Press.

Karns PD, Crichton VFJ: Effects of handling and physical restraint on blood parameters of woodland caribou. J. Wildl. Manag. 1978, 42, 904-908.

Klahr S, Hammermann MR, Martin K, Slatopolsky $E$ : Renal effects of parathyroid hormone and

calcitonin, pp 269-322, In: Dunn $M J$ (ed.): Renal Endocrinology. Williams and Wilkins, Baltimore, London. 1983.

Moate PJ, Scneider KM, Leaver DD, Morris DL: Effect of 1,25 dihydroxyvitamin D3 on the calcium and magnesium metabolism of lactating cows. Aust. Vet. J. 1987, 64, 73-75.

Mori S, Harada S, Okasaki R, Iroue D, Matsumoto T, Ogata E: Hypomagnesaemia with increased metabolism of parathyroid hormone and reduced responsiveness to calciotropic hormones. Intern. Med. 1992, 31, 820-824.

Nieminen $M$, Heiskari $U$ : Diets of free-living and captive reindeer during summer and winter. Rangifer 1988, 9, 17-34.

Quamme GA: Effect of hypocalcaemia on renal tubular handling of calcium and magnesium. Canad. J. Physiol. Pharmacol. 1982, 60, 1275-1280.

Reinhart RA: Magnesium metabolism. A review with special reference to the relationship between intracellular content and serum levels. Arch. Int. Med. 1988, 148, 2415-2420.

Saggese G, Frederico G, Bertelloni S, Siampero J, Baroncelli GJ, Calistri L: Hypomagnesaemia and the parathyroid - vitamin D endocrine system in children with insulin-dependent diabetes mellitus: Effects of magnesium administration. J. Pedriatr. 1991, 118, 220-225.

SAS Institute Inc.: SAS/STAT Guide for Personal Computers, Release 6.03. Ed. Cary, NC: SAS Institute Inc., 1988.

Shils $M E$ : Experimental human magnesium depletion. Medicine 1969, 48, 61-85.

Ahman B, Rydberg A, Ahman $G$ : Macrominerals in free-ranging Swedish reindeer during winter. Rangifer 1986, Special issue no. 1, 31-38. 


\section{Sammendrag}

Plasma magnesium, kalsium og uorganisk fosfor hos norsk tamrein (Rangifer tarandus tarandus) på vinterbeite.

I alt 1645 prøver av blodplasma ble samlet fra 2 reinflokker (Rengifer tarandus tarandus) i Nord-Norge (Magerøy- og Sørøyflokkene) og fra 2 flokker i SørNorge (Lom- og Filefjellflokkene) i perioden fra 1992 til 1995. Med unntak av 2 prøveserier fra Lomflokken $(\mathrm{N}=51 \mathrm{og} 56)$ ble alle prøver tatt enten i januar eller mars månded. Flokkenes ernæringsmessige tilstand varierte. Lomflokken hadde de beste vinterbeitene.

Plasmanivåene av magnesum (Mg), kalsium (Ca) og uorganisk fosfor $(\mathrm{P})$ ble målt. I tillegg ble plasma progesteron brukt som drektighetstest. Verdier $>7$ nmol $1^{-1}$ ble tolket som tegn på drektighet.

Gjennemsnittlige mineralkonsentrasjoner varierte betydlig mellom flokk og år. Den gjennomsnittlige (SD; min-max) konsentrasjon av $\mathrm{Ca}, \mathrm{Mg}$ and $\mathrm{P}$ i prøver samlet på vinterbeite var henholdsvis 2.42 (0.25; 0.9-3.6), $0.83(0.17 ; 0.16-1.39)$ og $1.70(0,47$;
0.2-3.4) $\mathrm{mmol} \mathrm{l}^{-1}$. Drektighetsprosenten for hele materialet var $79.8 \%$. Frekvensen av subnormale magnesiumverdier av magnesium $\left(\leq 0.7 \mathrm{mmol} \mathrm{l}^{-1}\right)$ og kalsium $\left(\leq 2.2 \mathrm{mmol}^{-1}\right)$ innen flokk og år varierte henholdsvis fra $0-61.9 \%$ og $1.4-44.9 \%$. Signifikante positive korrelasjoner ble funnet mellom kalsium og magnesium $\mathrm{i}$ alle flokker unntatt $\mathrm{i}$ Lomflokken hvor alle dyr hadde $\mathrm{Mg}$-verdier $>0.8 \mathrm{mmol} \mathrm{l}^{-1}$. De høyeste korrelasjoner mellom $\mathrm{Ca}$ og $\mathrm{Mg}$ ble funnet når $\mathrm{Mg}$ var lavt. Plasma $\mathrm{Mg}$ ga det største variansbidraget til $\mathrm{Ca}$ når den statistiske analysen omfattet effekter av flokk, prøveår, drektighetsstatus, alder og plasmakonsentrasjon $\mathrm{P}$. En nedgang i plasma $\mathrm{Mg}$ fra 1 til $<0.5 \mathrm{mmol} \mathrm{l}^{-1}$ var forbundet med en nedgang $\mathrm{i}$ plasma kalsium på omkring $15 \%$.

Gjennomsnittlig plasma $\mathrm{Mg}$ og Ca var signifikant høyere $(p<0.01)$ hos drektige enn hos ikke drektige dyr. En positiv sammenheng ble funnet mellom drektighetsprosent og de to nevnte mineraler.

Den positive korrelasjonen mellom $\mathrm{Ca}$ og $\mathrm{Mg}$ i flokker med subnormale $\mathrm{Mg}$ minima er i overensstemmelse med funn hos andre arter som indikerer at Ca-homeostasen hemmes ved magnesiummangel.

(Received november 20, 1996; accepted May 25, 1997).

Reprints may be obtained from: E. Ropstad, Department of Reproduction and Forensic Medicine, Norwegian College of Veterinary Medicine, P.O. Box 8146, Dep., N-0033, Oslo, Norway. E-mail: Erik.Ropstad@veths.no, tel: +47 229648 57, fax: +4722565704. 